\title{
Isolation and Characterization of Six Abscisic Acid-Inducible Genes from Carrot Somatic Embryos
}

\author{
Hajime SHIOTA ${ }^{1 *}$, Guangxiao YANG ${ }^{2}$, Shihua SHEN $^{2}$, Chang-Ho EUN ${ }^{2}$, Ken-ichi WATABE ${ }^{2}$, \\ Ichiro TANAKA ${ }^{1}$ and Hiroshi KAMADA ${ }^{2}$ \\ ${ }^{I}$ Graduate School of Integrated Science, Yokohama City University, Seto 22-2, Kanazawa-ku, \\ Yokohama 236-0027, Japan \\ ${ }^{2}$ Gene Research Center, University of Tsukuba, Tsukuba, Ibaraki 305-8572, Japan \\ *Corresponding author E-mail address: hshiota@yokohama-cu.ac.jp
}

Received 6 August 2004; accepted 13 October 2004 (Edited by M. Umeda)

\begin{abstract}
In carrot (Daucus carota L.) somatic embryos, desiccation tolerance is induced by treatment with abscisic acid (ABA). Six cDNA clones that showed ABA-enhanced expression were isolated from carrot by differential screening with $\mathrm{ABA}$ - treated and $\mathrm{ABA}$ - untreated somatic embryos, and they were named the CAISE (carrot ABA-induced in somatic embryos) genes. Five of the clones encode late embryogenesis abundant (LEA) proteins, and the other clone encodes a glucose and ribitol dehydrogenase. The expression of the CAISE genes was detected in maturing seeds, embryogenic cells, and $\mathrm{ABA}$ - treated somatic embryos in which exhibit desiccation tolerance induced by endogenous or exogenous $\mathrm{ABA}$. These results indicate that $\mathrm{ABA}$-induced desiccation tolerance in carrot somatic embryos may be induced by the LEA proteins and the glucose and ribitol dehydrogenase encoded by these $\mathrm{ABA}$ - inducible genes.
\end{abstract}

Accession numbers $\mathrm{AB} 105039, \mathrm{AB} 105040, \mathrm{AB} 105041, \mathrm{AB} 105042, \mathrm{AB} 105043, \mathrm{AB} 105044$.

Key words: abscisic acid (ABA), carrot (Daucus carota $\mathrm{L}$ ), somatic embryogenesis, seed desiccation tolerance.

\section{Abbreviations}

2,4-D, 2,4-dichlorophenoxyacetic acid; ABA, abscisic acid; DAF, days after flowering; ECP, embryogenic cell protein; LEA, late embryogenesis abundant; MS, Murashige and Skoog's medium.

Somatic embryogenesis has been extensively investigated as a model system for the development of zygotic embryogenesis. Carrot (Reinert, 1958; Steward et al., 1958), in particular, constitutes an important system for somatic embryogenesis studies, because numerous somatic embryos that are synchronized at various developmental stages can be readily induced by a simple procedure.

Despite their morphological similarities, zygotic embryos show desiccation tolerance and dormancy but somatic embryos do not (Iida et al., 1992). In the developing seeds of several higher plants, the endogenous level of abscisic acid (ABA) increases transiently just before the initiation of desiccation (Rock and Quatrano, 1995). Furthermore, ABA- deficient and ABA-insensitive mutants of Arabidopsis and maize produce seeds that do not exhibit desiccation tolerance or enter dormancy (Finkelstein et al., 2002). These observations indicate that $\mathrm{ABA}$ has important roles in the induction of desiccation tolerance and dormancy in seeds. However, the ABA content of carrot somatic embryos is low throughout the development of the embryo (Kiyosue et al., 1992a), and desiccation tolerance can be induced in alfalfa and carrot somatic embryos by ABA treatment (Senaratna et al., 1990; Iida et al., 1992). Therefore, somatic embryos may be able to acquire desiccation tolerance through exogenous application of ABA.

In many plant species, various late embryogenesis abundant (LEA) proteins accumulate in mature seeds, and the expression of most $L E A$ genes is positively regulated by ABA (Delseny et al., 2001). It seems likely that the LEA proteins function to protect cells against desiccation (Hoekstra et al, 2001). The VP1/ABI3 factor also plays important roles in seed-specific ABA signal transduction, 
controlling expression of some ABA-inducible genes, including the LEA genes (McCarty et al., 1991; Parcy et al., 1994). Using the carrot somatic embryogenesis system, we found that $\mathrm{C}-\mathrm{ABI} 3$, a carrot homolog of VP1 / ABI3, may be involved in ABA signal transduction, affecting the expression of certain embryo-specific ABA-inducible genes, including embryogenic cell protein (ECP) genes (Shiota et al., 1998; Shiota and Kamada, 2000).

In the present project, we isolated genes whose expression is enhanced in ABA-treated somatic embryos in order to investigate the molecular mechanisms related to the ABA-induced desiccation tolerance of somatic embryos.

Carrot (Daucus carota L. cv. US-Harumakigosun) seedlings were grown for 10 days at $25^{\circ} \mathrm{C}$ with $16 \mathrm{~h}$ of daily light at approximately 40 photons $\mathrm{m}^{-2} \mathrm{~s}^{-1}$. Carrot embryogenic cells and nonembryogenic cells were obtained, as described by Satoh et al. (1986). The small cell clusters of embryogenic cells (37-63 $\mu \mathrm{m}$ in size) were rinsed three times with liquid Murashige and Skoog (MS) medium (Murashige and Skoog, 1962), resuspended in liquid MS medium at a final density of $0.2 \mathrm{ml}$ packed cell volumes per liter, and cultured at $25^{\circ} \mathrm{C}$ in darkness on a gyratory shaker $(75 \mathrm{rpm})$. After 15 days of culture, torpedo-shaped somatic embryos were observed to have formed. Mature leaves were collected from plants that had been grown from somatic embryos for two months at $25^{\circ} \mathrm{C}$ with illumination, as described above. Seeds were collected from carrot plants (Daucus carota L. cv. Yohmeigosun) grown in the experimental field of the Takii Seed Co., Ltd. (Ushiku, Ibaraki, Japan). Seeds and fruits were harvested on various days after flowering (DAF).

Somatic embryos in 15-day-old-cultures were transferred to $100 \mathrm{ml}$ of fresh liquid MS medium containing ABA (3.7 $\mu \mathbf{M}$ or $10 \mu \mathrm{M})$ and cultured at $25^{\circ} \mathrm{C}$ for $1,3,5$, or 7 days in darkness on a gyratory shaker $(75 \mathrm{rpm})$. Similarly, non-embryogenic cells were cultured in $100 \mathrm{ml}$ of fresh liquid MS medium containing 2,4-dichlorophenoxyacetic acid (2,4-D; $\left.1 \mathrm{mg}^{-1}\right)$ and $\mathrm{ABA}(10 \mu \mathrm{M}$ or $100 \mu \mathrm{M})$ at $25^{\circ} \mathrm{C}$ for $24 \mathrm{~h}$ in darkness on a gyratory shaker $(100 \mathrm{rpm})$. Mature leaves of carrot plants were sprayed with $100 \mu \mathrm{M} \mathrm{ABA}$ and incubated for $8 \mathrm{~h}$ in darkness.

For preparation of the cDNA library and Northern blot analysis, total RNA was isolated from somatic embryos, non-embryogenic cells, and mature leaves (all of which had been treated with ABA or mock-treated), embryogenic cells, and developing seeds, according to the method described by Ausubel et al. (1987) with modifications. Poly (A) ${ }^{+}$RNA was isolated, using the mRNA Purification Kit
(Amersham Biosciences), from total RNA of somatic embryos that had been treated with ABA or mock - treated. cDNA was synthesized from the poly $(\mathrm{A})^{+}$ RNA using the cDNA Synthesis System Plus (Amersham Biosciences). A cDNA library of ABA treated somatic embryos was constructed in lambda gt10 using a mixture of cDNAs from ABA-treated (10 $\mu \mathrm{M} ; 1-7$ days) somatic embryos and a cDNA Cloning System (Amersham Biosciences). All procedures were carried out according to the protocols provided by the suppliers.

Differential screening was performed by plaque hybridization. A total of approximately 40,000 plaques of recombinant phages were plated and transferred onto nylon filters (Hybond- $\mathrm{N}^{+}$; Amersham Biosciences). [ $\left.{ }^{32} \mathrm{P}\right]$-labeled cDNA fragments from ABA-treated (10 $\mu \mathrm{M} ; 1-7$ days) and mocktreated somatic embryos were used as positive and negative control probes, respectively. Hybridization was performed at $65^{\circ} \mathrm{C}$, as directed by the manufacturer (Amersham Biosciences). Radioactivity on the filters was detected using the BAS 2000 system (Fuji Photo Film). The isolated lambda gt10 phage DNAs were digested with $E c o$ RI and the insert fragments were subcloned into the pBluescript II $\mathrm{SK}^{+}$vector (Stratagene). To sequence the cDNA clones, double-stranded plasmid DNAs were isolated and sequenced using the dye terminator cycle sequencing method with the Dye Terminator Cycle Sequencing Kit (Applied Biosystems).

Total RNA $(20 \mu \mathrm{g})$ was loaded on an agarose $(1.2 \%)$ gel containing $0.66 \mathrm{M}$ formaldehyde, separated by electrophoresis, and transferred to GeneScreen Plus nylon filters (New Research Products). Hybridization was performed at $60^{\circ} \mathrm{C}$, according to the manufacturer's instructions. Autoradiography was performed at $-80^{\circ} \mathrm{C}$ using Biomax MS film (Eastman Kodak).

In this project, we attempted to isolate $\mathrm{ABA}$ inducible genes from $\mathrm{ABA}$-treated carrot somatic embryos using differential screening. Over 200 positive clones were isolated from approximately 40,000 plaques of a cDNA library constructed from $A B A$-treated somatic embryos, and the clones were classified into six groups that did not cross-hybridize in dot-blot analyses (data not shown). The six positive clones were isolated and named the CAISE (carrot $A B A$-induced in somatic embryos) genes (CAISE1, CAISE2, CAISE3, CAISE4, CAISE5, and CAISE6) (Table 1). In Northern blot analysis, the CAISE1, CAISE2, CAISE3, CAISE4, CAISE5 and CAISE6 probes hybridized to RNAs of $0.8,1.1,0.8$, $0.6,1.3$, and $1.2 \mathrm{~kb}$, respectively (Fig. 1). Expression of each of the clones was detected in ABA untreated somatic embryos and was enhanced by 
ABA treatment (10 $\mu \mathrm{M}, 7$ days) (Fig. 1). The CAISE gene expression in the ABA-untreated embryos may have been induced by endogenous $A B A$, since carrot somatic embryos contain low levels of endogenous ABA (Kiyosue et al., 1992a).

CAISE2 and CAISE6 were found to be identical to the carrot genes ECP3I and ECP40, respectively (Table 1) (Kiyosue et al., 1992b; Kiyosue et al., 1993). ECP31 and ECP4O belong to the LEA gene families and are expressed in embryogenic cells, developing seeds, and ABA-treated somatic embryos (Kiyosue et al., 1992b; Kiyosue et al., 1993). CAISE4 encodes a protein identical to that encoded

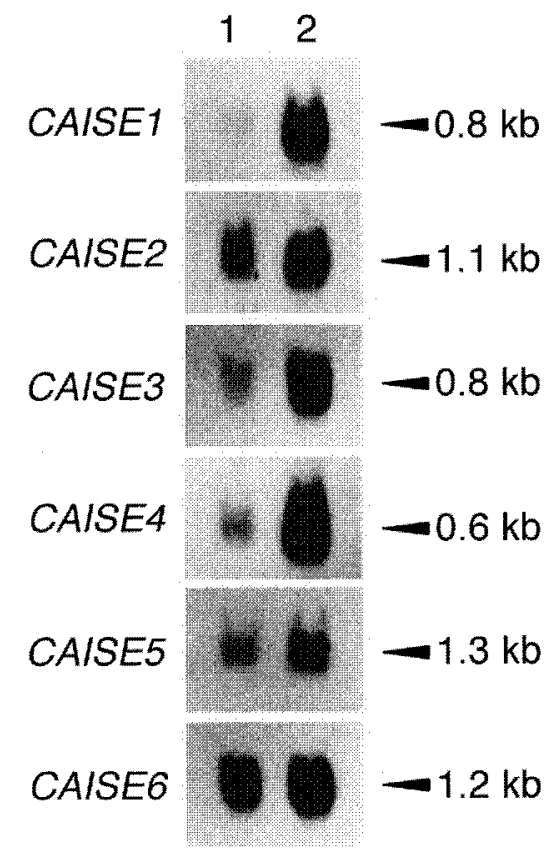

Fig. 1 Northern blot analysis of the expression of the CAISE genes in carrot somatic embryos.

Twenty micrograms of total RNA from torpedo-shaped embryos that were mock-treated (lane 1) or treated with ABA (lane 2) were fractionated by gel electrophoresis, and transcripts were allowed to hybridize with $\left[{ }^{32} \mathrm{P}\right]-$ labeled cDNA fragments of the CAISE genes. For $\mathrm{ABA}$ treatment, $10 \mu \mathrm{M} \mathrm{ABA}$ was added and the samples were incubated for seven days. by the carrot gene EMB1 (Table 1, Fig. 2) (Wurtele et al., 1993), although the nucleotide sequences in the 3 - untranslated regions of these genes have only $73 \%$ homology (data not shown). It is possible that these two genes are identical, with the differences in the nucleotide sequences derived from different carrot cultivars. $E M B 1$ has homology to the wheat $E m$ gene and is expressed in developing somatic embryos, with expression gradually increasing during development (Wurtele et al., 1993). The deduced amino acid sequence of CAISE 3 has significant homology to those of $E m$-like genes of several plant species (Table 1) (Manickam et al., 1996; Delseny et al., 2001). CAISE3 is also highly similar to CAISE4, although CAISE3 contains a 20 -amino - acid sequence not present in CAISE4 (Fig. 2). In the genomes of some plant species, the presence of multiple classes of $E m$-like genes has been reported (Manickam et al., 1996; Delseny et al., 2001). These facts indicate that both CAISE3 and CAISE4 are carrot $E m$-like genes. CAISEI encodes a type of dehydrin protein (Table 1), based on the presence of three characteristic dehydrin segments: the $\mathrm{K}$ segment, the S segment, and the Y segment (data not shown) (Baudo et al., 1996). Thus, five of the CAISE genes encode LEA proteins. In general, the LEA proteins help maintain the stability of cellular components and proteins through the solubilization of substances during desiccation (Hoekstra et al., 2001). It seems likely that the products of these five CAISE genes protect cells against dehydration in $\mathrm{ABA}$ - treated carrot somatic embryos.

The remaining CAISE gene, CAISE5, has significant homology to glucose and ribitol dehydrogenase genes of barley and lupin (Table 1) (Alexander et al., 1994; Francki et al., 2002). These genes are expressed specifically during embryogenesis, with increased expression at the seed maturation stage (Alexander et al., 1994; Francki et al., 2002). During the acquisition of desiccation tolerance in seeds, sugars accumulate, maintaining the stability of membranes and functional proteins by replacing the water molecules at the charged

Table 1. Summary of cDNA clones isolated from ABA-treated carrot somatic embryos by differential screening.

\begin{tabular}{ccclc}
\hline Gene name & Length of clones (bp) & $\begin{array}{c}\text { Predicted size of gene } \\
\text { products (a. a.) }\end{array}$ & $\begin{array}{c}\text { Homologous protein } \\
\text { products (species) }\end{array}$ & Accession No. \\
\hline CAISE1 & 771 & 149 & DHN1 (potato) & Y15813 \\
CAISE2 & 982 & 256 & ECP31 (carrot) & X60593 \\
CAISE3 & 778 & 113 & Em-like (mung bean) & U31210 \\
CAISE4 & 523 & 92 & EMB1 (carrot) & X17608 \\
CAISE5 & 1179 & 291 & pG31 (barley) & S72926 \\
CAISE6 & 1120 & 306 & ECP40 (carrot) & X61914 \\
\hline
\end{tabular}




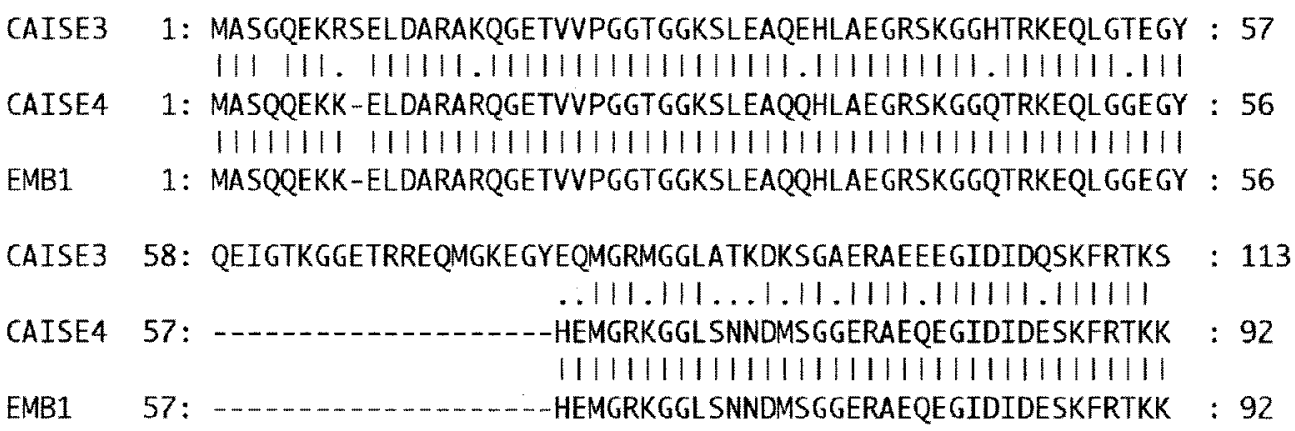

Fig. 2 Alignment of the deduced amino acid sequences of the carrot Em-like genes CAISE3, CAISE4, and EMB1.

An alignment of the deduced amino acid sequences of CAISE3, CAISE4, and EMBI (accession no. X17608) is presented. Identical amino acid residues are shown connected with a line. Single dots indicate similar amino acids. Gaps introduced to optimize the alignments are indicated by hyphens.

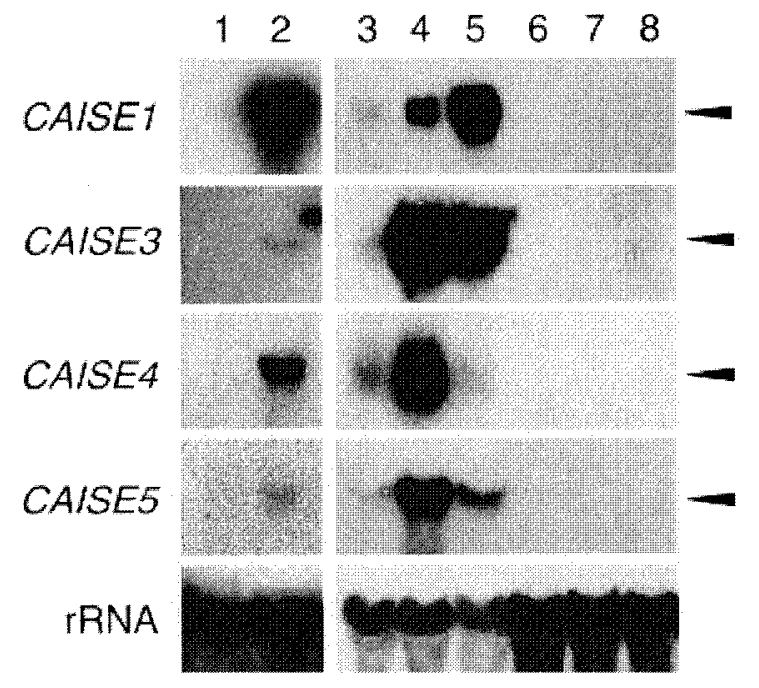

Fig. 3 Northern blot analysis of expression of the CAISE genes in mature leaves, somatic embryos, embryogenic cells, and non-embryogenic cells.

Total RNA was isolated from mature leaves (lanes 1 and 2), torpedo-shaped somatic embryos (lanes 3 and 4), embryogenic cells (lane 5), and non-embryogenic cells (lanes 6, 7, and 8). The leaves were either mock - treated (lane 1) or treated with ABA (100 $\mu \mathrm{M}$ for $8 \mathrm{~h}$ ) (lane 2). Somatic embryos and non-embryogenic cells were treated with $0 \mathrm{M}$ (lanes 3 and 6), $3.7 \mu \mathrm{M}$ (lane 4), $10 \mu \mathrm{M}$ (lane 7), or $100 \mu \mathrm{M}$ (lane 8) ABA for $24 \mathrm{~h}$. Twenty micrograms of total RNA per sample were fractionated by gel electrophoresis and allowed to hybridize with $\left[{ }^{32} \mathrm{P}\right]$ labeled cDNA fragments of CAISE1, CAISE3, CAISE4 or CAISE5. The blot was reprobed with labeled $18 \mathrm{~S}$ rRNA to provide an internal standard.

surfaces (Hoekstra et al., 2001). Therefore, CAISE5 might function as a short alcohol-polyol-sugar dehydrogenase, possibly related to carbohydrate

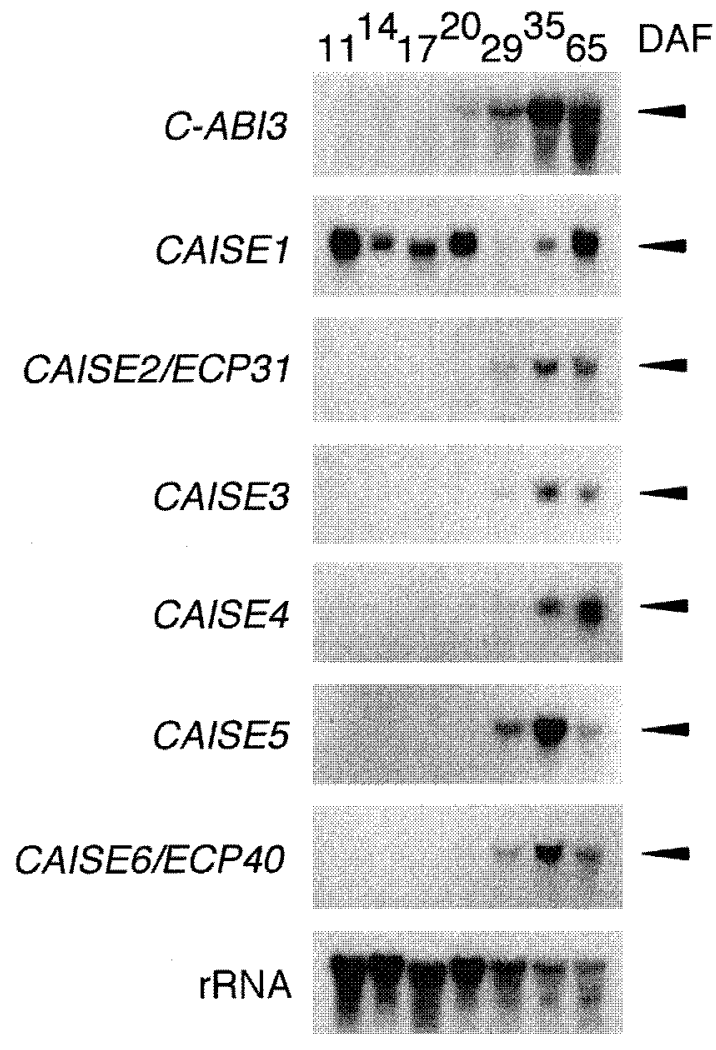

Fig. 4 Northern blot analysis of the expression of $C$ $A B I 3$ and the CAISE genes in developing carrot seeds.

Twenty micrograms of total RNA from seeds at various DAF, as indicated, were fractionated by gel electrophoresis and allowed to hybridize with $\left[{ }^{32} \mathrm{P}\right]$-labeled cDNA fragments of $C-A B I 3$, CAISE1, CAISE2/ECP31, CAISE3, CAISE4, CAISE5 or CAISE6/ECP40. The blot was reprobed with labeled $18 \mathrm{~S}$ rRNA to provide an internal standard.

metabolism and the acquisition of desiccation tolerance in $\mathrm{ABA}$-treated somatic embryos (Alexander et al., 1994). On the other hand, it has been recently 
proposed that sugars are involved in phytohormone signaling during plant growth and development (León and Sheen, 2003). Thus, CAISE5 might also have roles in signal transduction mechanisms.

Transcripts of each of the CAISE genes, were detected in embryogenic cells, somatic embryos, and seeds in the later stages of development, but not in non-embryogenic cells with or without $A B A-$ treatment (Figs. 1, 3 and 4) (Shiota and Kamada, 2000). In somatic embryos, the expression of all of the CAISE genes was enhanced after an ABA treatment that was shorter and of a lower concentration than usual (3.7 $\mu \mathrm{M}, 24 \mathrm{~h}$ ) (Fig. 3) (Shiota and Kamada, 2000). Maturing seeds, embryogenic cells, and ABA-treated somatic embryos exhibit desiccation tolerance induced by endogenous or exogenous ABA (Iida et al., 1992; Kiyosue et al., 1992a; Shiota et al., 1998), and the CAISEs may be involved in $\mathrm{ABA}$-induced desiccation tolerance in zygotic and somatic embryos.

Zygotic and somatic embryos that show ABAinduced desiccation tolerance may have the tolerance against water loss from cells, because the relative water content of desiccated embryos fall to about 5\% (Shiota et al., 1998). In carrot somatic embryos, the extent of desiccation tolerance increases gradually during the first 8 days of $\mathrm{ABA}$ treatment, although the weak tolerance is induced by just 30 h of ABA-treatment (Iida et al., 1992). On the other hand, the CAISE genes were strongly expressed in somatic embryos treated with a shorter - term (24 h) ABA, and levels of the expression were maintained during at least 7 days of ABAtreatment (Figs. 1 and 3). Therefore, it is suggested that the accumulation of several components whose synthesis is induced by ABA, such as the products of the CAISE genes, might be a prerequisite for the protection of cells against damage by water loss, and the accumulation might require at least 8 days of $\mathrm{ABA}$ - treatment in somatic embryos.

In developing seeds, the expression of all of the CAISE genes increased during the seed maturation phase (after 29 DAF) (Fig. 4). The CAISE2/ECP31, CAISE3, CAISE4, CAISE5 and CAISE6/ECP40 transcripts were confined to seeds after $29 \mathrm{DAF}$ (Fig. 4). In carrot seeds, the water content begins to decrease after $38 \mathrm{DAF}$, and endogenous levels of ABA increase after 23 DAF, with a transient peak at 29 DAF (Shiota et al., 1998). These results suggest that the CAISE genes are induced by a programmed increase in endogenous ABA during seed maturation. In contrast, the expression of CAISE1 was observed throughout seed development, and the level of the expression was higher in the early stage of seed development (11-20 DAF) (Fig. 4). Many dehydrin genes are induced not only by ABA but also by several environmental factors (Nylander et al., 2001). In fact, the expression of CAISE1 was induced in carrot leaves by drought, salinity, and cold and heat stresses (data not shown). The transcription of CAISE1 at 11-20 DAF may be induced by environmental factors (e.g. low temperature or drought), because the endogenous ABA level was low in seeds at 11-20 DAF (Shiota et al., 1998). Therefore, the expression of CAISE1 may be controlled independently by endogenous $\mathrm{ABA}$ and environmental factors.

The expression of all of CAISE genes was not detected in mature leaves without ABA-treatment (Fig. 3) (Shiota et al., 1998). In ABA-treated leaves, strong ABA-inducible expression of CAISE1 and CAISE4 was detected, and weak expression of CAISE3 and CAISE5 was also ob served (Fig. 3). CAISE2/ECP31 and CAISE6/ECP4O as embryo-specific $A B A$-inducible genes show no $\mathrm{ABA}$-inducible expression in mature leaves (Kiyosue et al., 1992b; Kiyosue et al., 1993; Shiota et al., 1998). These results suggest that the embryo specificity of the expression of CAISE3 and CAISE5 may be higher than that of CAISE1 and CAISE4. In seeds of higher plants, the VP1 / ABI3 factor functions as a transcriptional factor in $\mathrm{ABA}$-induced gene expression (McCarty et al., 1991; Parcy et al., 1994). During carrot seed development, $C-A B I 3$ is expressed prior to the increase in endogenous $A B A$ levels and the ABA-induced expression of the $C A I S E$ genes, since $C-A B I 3$ transcripts were detected after 20 DAF (Fig. 4) (Shiota et al., 1998). Therefore, $\mathrm{C}-\mathrm{ABI} 3$ might control the expression of CAISE genes in carrot embryos. In order to clarify whether the CAISE genes are actually controlled by $\mathrm{C}-\mathrm{ABI} 3$, expression analysis of the CAISE genes is now been performed using transgenic plants in which $C-A B I 3$ is expressed ectopically.

Based on these results, we propose that many ABA-inducible genes such as CAISEs and ECPS are involved in $A B A$ - induced desiccation tolerance in zygotic and somatic embryos. The desiccation tolerance in these embryos may be induced by accumulation of sufficient levels of components that are involved in the protection of cells against damage by desiccation, including LEA proteins, heat shock proteins, and sugars.

\section{Acknowledgements}

This research was supported in part by a Grant-in - Aid for Research on Priority Areas and for Scientific Research from the Ministry of Education, Science, Culture, and Sports, Japan; by a Grant-inAid from the "Research for the Future" Program 
from the Japan Society for the Promotion of Science (JSPS-RFTF00L01601); and by the Special Coordination Funds of the Science and Technology Agency of the Japanese Government.

The authors are grateful to the staff of the Ibaraki Experimental Field of the Takii Seed Co., Ltd. for collecting carrot seeds.

\section{References}

Alexander, R., Alamillo, J.M., Salamini, F., Bartels, D. 1994. A novel embryo-specific barley cDNA clone encodes a protein with homologies to bacterial glucose and ribitol dehydrogenase. Planta, 192: 519-525.

Ausubel, F.M., Brent, R., Kingston, R.E., Moore, D.D., Seidman, J.G., Smith, J.A., Struhl, K. 1987. Phenol/SDS method for plant RNA preparation. In: Ausubel, F.M. et al. (Eds.): Current Protocols in Molecular Biology, Vol. 4.3.1-4.3.4. Greene Publishing Associates and Wiley-Interscience, New York.

Baudo, M. M., Meza-Zepeda, L.A., Palva, E.T., Heino, P., 1996. Induction of homologous low temperature and $\mathrm{ABA}$ responsive genes in frost resistant (Solanum commersonii) and frost sensitive (Solanum tuberosum cv. Bintje) potato species. Plant Mol. Biol., 30: 331 336.

Delseny, M., Bies-Etheve, N., Carles, C., Hull, G., Vicient, C., Raynal, M., Grellet, F., Aspart, L., 2001. Late Embryogenesis Abundant (LEA) protein gene regulation during Arabidopsis seed maturation. J. Plant Physiol., 158: 419-428.

Finkelstein, R.R., Gampala, S.S., Rock, C.D., 2002. Abscisic acid signaling in seeds and seedlings. Plant Cell, 14: $\mathrm{S} 15-\mathrm{S} 45$.

Francki, M. G., Whitaker, P., Smith, P. M., Atkins, C. A., 2002. Differential expression of a novel gene during seed triacylglycerol accumulation in lupin species (Lupinus angustifolius L. and L. mutabilis L.). Funct. Integr. Genomics, 2: 292-300.

Hoekstra, F.A., Golovina, E.A., Buitink, J., 2001. Mechanisms of plant desiccation tolerance. Trends Plant Sci., 6: $431-438$.

Iida, Y., Watabe, K., Kamada, H., Harada, H., 1992. Effects of abscisic acid on the induction of desiccation tolerance in cartot somatic embryos. J. Plant Physiol., 140: $356-360$.

Kiyosue, T, Nakajima, M., Yamaguchi, I., Iida, Y., Satoh, S., Kamada, H., Harada, H., 1992a. Endogenous level of abscisic acid in embryogenic cells, non-embryogenic cells and somatic embryos of carrot (Daucus carota L.). Biochem. Physiol. Pflanzen, 188: 293-297.

Kiyosue, T., Yamaguchi-Shinozaki, K., Shinozaki, K., Higashi, K., Satoh, S., Kamada, H., Harada, H., 1992 b. Isolation and characterization of a cDNA that encodes ECP31, an embryogenic-cell protein from carrot. Plant Mol. Biol., 19: 239-249.

Kiyosue, T., Yamaguchi-Shinozaki, K., Shinozaki, K., Kamada, H., Harada, H., 1993. cDNA cloning of ECP40, an embryogenic-cell protein in carrot, and its expression during somatic and zygotic embryogenesis. Plant Mol. Biol., 21: 1053-1068.

León, P., Sheen, J., 2003. Sugar and hormone connections. Trends Plant Sci., 8: 110-116.

Manickam, A., Van Damme, E.J.M., Kalaiselvi, K., Verhaert, P., Peumans, W.J., 1996. Isolation and cDNA cloning of an Em-like protein from mung bean (Vigna radiata) axes. Physiol. Plant., 97: 524-530.

McCarty, D.R., Hattori, T., Carson, C.B., Vasil, V., Lazar, M., Vasil, I. K., 1991. The viviparous -1 developmental gene of maize encodes a novel transcriptional activator. Cell, 66: 895-905.

Murashige, T., Skoog, F., 1962. A revised medium for rapid growth and bioassays with tobacco tissue cultures. Physiol. Plant., 15: 473-497.

Nylander, M., Svensson, J., Palva, E.T., Welin, B.V., 2001. Stress-induced accumulation and tissue-specific localization of dehydrins in Arabidopsis thaliana. Plant Mol Biol, 45: 263-279.

Parcy, F., Valon, C., Raynal, M., Gaubier-Comella, P., Delseny, M., Giraudat, J., 1994. Regulation of gene expression programs during Arabidopsis seed development: roles of the $A B I 3$ locus and of endogenous abscisic acid. Plant Cell, 6: 1567-1582.

Reinert, J. 1958. Untersuchungen über die Morphogenese an Gewebekulturen. Ber. Dtsch. Bot. Ges., 71: 15.

Rock, C.D., Quatrano, R.S., 1995. The role of hormones during seed development. In: Davies, P. J. (Eds.): Plant Hormones: Physiology, Biochemistry and Molecular Biology, pp. 671-697. Kluwer Academic Publishers, Dordrecht.

Satoh, S., Kamada, H., Harada, H., Fujii, T, 1986. Auxincontrolled glycoprotein release into the medium of embryogenic carrot cells. Plant Physiol., 81: 931-933.

Senaratna, T., McKersie, B.D., Bowley, S.R., 1990. Artificial seeds of alfalfa (Medicago sativa L.). Induction of desiccation tolerance in somatic embryos. In Vitro Cell. Dev. Biol., 26: 85-90.

Shiota, H., Kamada, H., 2000. Acquisition of desiccation tolerance by cultured carrot cells upon ectopic expression of $\mathrm{C}-\mathrm{ABI3}$, a carrot homolog of $\mathrm{ABI} 3$. J. Plant Physiol., 156: 510-515.

Shiota, H., Satoh, R., Watabe, K., Harada, H., Kamada, H., 1998. C-ABI3, the carrot homologue of the Arabidopsis $A B I 3$, is expressed during both zygotic and somatic embryogenesis and functions in the regulation of embryo-specific ABA-inducible genes. Plant Cell Physiol., 39: 1184-1193.

Steward, F. C., Mapes, M. O., Mears, K., 1958. Growth and organized development of cultured cells. II. Organization in cultures grown from freely suspended cells. Amer. J. Bot., 45: 705-708.

Wurtele, E. S., Wang, H., Durgerian, S., Nikolau, B. J., Ulrich, T. H., 1993. Characterization of a gene that is expressed early in somatic embryogenesis of Daucus carota. Plant Physiol., 102: 303-312. 